\title{
CHILD'S MUSICAL PERCEPTION DEVELOPMENT IN EARLY YEARS
}

\author{
Anna Līduma \\ Riga Teacher Training and Educational Management Academy, Latvia
}

\begin{abstract}
This research is an analysis of the succession in the child's musical perception development. The theory based experimental study of the gradual development of musical perception revealed the specifics of children's musical perception formation from prenatal period to the age of 3. The formation of the sensory and vocal experience in early years, and purposeful activity at the realization of the connection of memory and thinking in conjunction with listening to music are analyzed. The author has observed that both stages of musical perception in the early genesis: sensory and motor and a perceptive activity; perceptive activity gets developed during purposeful musical everyday actions. On the basis of pedagogical observations and self-experience at preschool, the role of adult's purposeful activity in the timely started promotion of the child's musical perception is highlighted.
\end{abstract}

Keywords: child's music perception, musical hearing notions, musicality, communication.

\section{Introduction}

The musicality of the Latvian nation is being manifested since 1873 by the Song Festivals, and now Latvians from all over the world regularly take part in the Song and Dance Festival every fifth year. Preschool children and pupils demonstrate their musicality at the School Youth Song and Dance Festivals and other competitions. In order to organize mutual song festivals, the singers have to possess miscellaneous musical abilities and skills. For this reason, ability development and skills are being developed during a long period of time and every individual possesses a different development tempo and the level reached. Therefore, the research was needed on the musical perception development in the early years of childhood (0-3) and has been carried out in two stages. During the period from 1998 to 2002 the author studied musicality development in preschool children in accordance with the findings regarding the entirety of child's development. In order to test in practice the obtained results by the research, the research was continued on the child musicality development dynamics further on from 2002 to 2012. The purpose was to establish musical perception development peculiarities in children and to find out pedagogical means for the child's musical perception development fostering at preschool age. 
According to some important findings, humans are able to hear sounds before they are born and receive the first musical impressions in the prenatal period. Emotional responsiveness is an inborn quality (Liduma, 2015, 250). At the age of two to four months, a baby gradually acquires the ability of discerning sound timbre and rhythm parameters. The dynamic hearing is developed for a longer time. A child's development is adversely affected by loud music and the child becomes agitated. It was observed that even 9 to 10 year-old children felt unwell because of loud music. It can be explained by the fact that aural canal walls ossify at the age of about 10 years, whereas the development of the auditory apparatus as a whole completes approximately by the age of 12 . Preschool teachers and sound operators should understand that as opposed to the child the adult perceives 16000 - 20000 sound oscillations per second (some up to 30000), while the child's ear perceives up to 32000 sound oscillations per second. Auditory perception is the most acute from the age of 14 to 19 (Гальперин, 1965, 115-116; Fassbender, 1996).

The study is based on the theories of the 'holistic approach' to child's musicality development at preschool (Līduma, 2015) and the conclusions on the musical perception formation stages (Готсдинер, 1974). The study has made use of the empirical research methods including: experimental analysis, analysis of the data of interviews with children and their parents and pedagogical observations.

The aim of the paper is to assist preschool pedagogues and adults in more purposeful promotion of children's musical perception.

\section{Succession in development of musical perception}

In the first stage of the research during the theoretical sources' studies on musicality, the opinions of psychologists on the child musical ability development were discovered. On the basis of the established verities and by following the holistic approach to the child holistic and musical ability development, the author of the article defined the musicality. Musicality is an integrated and united personal feature, which comprises emotional perception and emotional responsiveness, musical hearing, sense of rhythm, vocal range, singing skills quality of singing and musical thinking and musical memory (Lìduma, 2004, 94).

Such verities as the musicality structure involves interconnected musical abilities that were gained by the research are significant. It is important for the child development that one musical ability development level has impact on the level of other ability development. Uneducated musical perception can hinder the musical hearing development, but a poor musical hearing prevents development of the vocal range and singing skill. The development of musical 
skills starts as soon as the child was born, and the basis of it is the emotional responsiveness as an inborn quality (Liduma, 2015, 250).

Characterizing the inborn and the acquired musical abilities, V. Myasichev and A. Gotsdiner explain that the ability of analyzing specific sound signals speech and music - is inborn and genetically inherited, and it evolved in the process of human evolution; whereas sound discernment degree, differentiation acuity and singing skills are acquired during one's lifetime (Мясищев \& Готсдинер, 1992). The pedagogical observation confirms the discovery in the theoretical sources that each child develops its music perception, sound differentiation level and skills of singing highly individually. The level acquired during one's lifetime is determined by the training and upbringing process and the actual speech and musical experience in a certain social and concrete musical cultural environment (Līduma, 2015, 258).

\section{Perception development in the prenatal period}

While researching theoretical sources on prenatal period, it was found that a fetus of 4-5 weeks can hear heartbeats, mother's voice, body sounds. According to theoretic data, the child's perception of sounds is very sensitive in the prenatal period. Acoustic signals considerably stimulate morphological (structural) and psychological perception level starting as early as the eight weeks of the prenatal period. A child can hear sounds well starting already from about Week 26, but starting from Week 32 the baby is able to perceive audible irritants and react to unpleasant sounds by restless movements while still in the womb, and from Week 36 - to distinguish the mother's singing from that of another person. Sound perception is especially good in the last week of the prenatal period, and the child can hear a song, which is sung to it or a tale which is told (Līduma, 2015, 45-46).

Table 1 Succession in development of musical perception

\begin{tabular}{|l|l|}
\hline Week & Prenatal period \\
\hline $4-5$ & Can hear heartbeats, mother's voice, body sounds \\
\hline 8 & $\begin{array}{l}\text { Acoustic signals considerably stimulate morphological (structural) and } \\
\text { psychological perception level }\end{array}$ \\
\hline 26 & A child can hear sounds well \\
\hline 32 & $\begin{array}{l}\text { The baby is able to perceive audible irritants and react to unpleasant sounds by } \\
\text { restless movements }\end{array}$ \\
\hline 36 & \begin{tabular}{l} 
Is able to distinguish the mother's singing from that of another person. \\
\hline $\begin{array}{l}\text { Last } \\
\text { week }\end{array}$
\end{tabular} $\begin{array}{l}\text { Sound perception is especially good, and the child can hear a song, which is sung or } \\
\text { a tale which is told }\end{array}$ \\
\hline
\end{tabular}


It means that the organs of senses are ready to perceive and react to specific irritants as early as a few weeks before the child's birth. The hearing zone is mature enough to perceive speech actively. An interaction between the biological (genetic) factor and social factor (hearing as the main communication means) is evident. According to the psychologists' conclusions a newborn baby's senses (touch, vision, hearing, taste) are influenced by the environment in three ways - physically, biologically and socially (Готсдинер, 1974, 231).

\section{Musical perception development characteristics in the first year of life}

The studies have confirmed that even a 1.5-2 months old baby reacts not just to the color and form of a rattle but also to the rattle sounds of various strength and nature. A baby of 4-5 months can feel the adult's mood, respond to emotional and expressive music of sad (minor) or merry (major) nature. It was shown that a baby of 5-6 months was able of differentiating music by genre elements (Papoušek, 1996, 49). As a baby at the age of 3-4 months can hear sounds within the intervals of 16 musical tones only, the child's musical perception must be purposefully promoted during the first year of life since auditory perception plays a fundamental role in child's emotional development (Lìduma, 2015, 47) (See Table 1).

The data of the interviews with parents show that the most significant for development of child's voice is the sound of the human voice; therefore, mothers should sing songs every day, since adult singing has the most favorable impact on the development of hearing, rhythm and memory in infants. During the first year of life, a baby cannot yet perceive a melody as a whole, however, he can feel music nature and emotions; therefore, auditory perception is stimulated by listening to music of different nature - a lullaby, a dance song. It was observed that at the age about 6 months a child is able to lull itself to sleep by making sounds with one's voice, and at the age of 10 months - smile and react with motions when hearing dance music. Depending on the child's mood, the adults must often sing an appropriate melody of calm or proactive nature. A baby of 7 months can differentiate sounds with a half-tone $(1 / 2)$ interval. It is necessary to notice that according to notions of the psychologist C. L. Krumhansl, the half-tone interval is equal to one musical tone. The musical tone peculiarity depends on the peculiar status of intervals. In music theory, an interval is the distance between two pitches (notes). In Western music the smallest interval used is $\mathrm{m}^{2}$ or $1 / 2$ tone (100 cents). The chromatic scale consists of 12 tones with measure unit of $1 / 2$ tone $=1$ musical tone. It means that the Major scale consists of 12 musical tones: 2212221 , and the qualitative sound pitch indicator between the pitches is: 1, 1, 1/2, 1, 1, 1, 1/2 (Krumhansl, 2000, 364; Interval (music), 2015; Līduma, 2015, 48). 
Thus, at the above-mentioned period it is desirable to encourage the child to sing. Singing promotes musical hearing development, and, therefore, auditory perception, which, in its turn, instigates the development of auditory memory and hearing notions. Musical hearing notions means children's inner hearing and develops gradually from birth (Joffe, 1991, 10-11). In practice it is observed that the preschool child's perception is slow. The sound differentiation in the early years develops gradually and successively, yet the opinions differ on the amount of quantitative and qualitative differentiation (Interval (music), 2015), as clearly seen in the following table revealing opinions of 2 authors (see Table 2 and Table 3).

Table 2 Sequence of formation of sound differentiation (according to S. Galperin, 1965)

\begin{tabular}{|l|l|}
\hline Age & Sound intervals (sounding) \\
\hline 3 to 3.5 months & P11 (perfect eleventh) 17 musical tones \\
\hline 4.5 months & m9-M9 (minor, major ninth) $13-14$ musical tones \\
\hline By end of $5^{\text {th }}$ month & P5 $-\mathrm{m} 7$ (perfect fifth to minor seventh) $7-10$ musical tones \\
\hline In the $6^{\text {th }}$ month & m3-P4 (minor third to perfect fourth) $3-5$ musical tones \\
\hline $6^{\text {th }}-7^{\text {th }}$ month & $\begin{array}{l}\mathrm{m} 2-\mathrm{M} 2(1-2 \text { tones) or } 1 / 2 \text { and } 3 / 4 \text { tone (half a tone and three- } \\
\text { fourths of a tone) }\end{array}$ \\
\hline $\begin{array}{l}\text { At the age of six to seven months the child's auditory perception almost corresponds to the } \\
\text { adult auditory perception. }\end{array}$ \\
\hline
\end{tabular}

Table 3 Sequence of formation of sound differentiation (according to A. Gotsdiner, 1974)

\begin{tabular}{|l|l|}
\hline Age & Sound intervals \\
\hline 3 to 3.5 months & P8-M10 (perfect octave to Major tenth) 16 musical tones \\
\hline 4.5 months & M7-9 (major seventh to ninth) $11-13$ musical tones \\
\hline By end of $5^{\text {th }}$ month & A4-M6 (augmented fourth to major sixth) 6-9 musical tones \\
\hline $\begin{array}{l}\text { Intensive sound pitch differentiation takes place starting from the beginning of the } 6^{\text {th }} \\
\text { month and, especially, from the end of the } 7^{\text {th }} \text { month }\end{array}$ \\
\hline At start of $6^{\text {th }}$ month & Discerns M2 (major second) -2 musical tones \\
\hline By end of $7^{\text {th }}$ month & $\begin{array}{l}\text { minor } 2-1 / 2 \text { tone }-3 / 4 \text { tone }(100-150 \text { cents) half a tone and three- } \\
\text { fourths of a tone }\end{array}$ \\
\hline
\end{tabular}

It is necessary to note that in accordance with the findings of A. Arismendi and G. Craig, the volume of a newborn baby's brain is $25 \%$ of the brain mass of an adult, at the age of 9 months $-50 \%, 2$ years old $-75 \%, 6$ years old $-90 \%$, and the remaining 10\% appear within the next 10 years (Arismendi, 1989, 4849, Крайг, 2000, 242-354).

In observance of the development sequence, during the first year of life child's activity must be stimulated by singing, talking, playing. Adults must sing 2 or 3 times slower than the indicated tempo (Радынова et al., 1994). 
Researchers believe that abilities develop most intensively during the period when a baby has already learned to crawl but does not speak yet. According to B. Nikitin and L. Nikitina, the opportunities for development of child's abilities, having reached the maximum to start the development process, will not stay unchanged at the maturity point. If the necessary kinds of activities are missing, child's abilities start disappearing (Никитин \& Никитина, 1989, 273). Fast brain development is functional. Information is gained through the human's sensory canals, and hearing is the most emotionally significant of those. Both brain hemispheres perceive music: the right-sided perceives a melody, the leftsided - rhythm. This is a reason why it is very important in early years purposefully promote a well-balanced development of child's brain hemispheres (Liduma, 2004). An important finding is that in the prenatal period and babyhood the brain is much more responsive to the ambient environment than it was earlier assumed; therefore, to start developing a child's abilities in a kindergarten means to miss the musicality development opportunities (Papoušek, 1996).

\section{Means for the child's voice development and musical experience fostering}

Baby's sensory voice development sensation starts with the first sound sensations before it is born - in the prenatal period (Готсдинер, 1974). Those sensations may arouse various emotions in the baby - positive, negative or indifferent. Baby's first involuntary voice sounds are sounds of crying, whereby the baby shows dissatisfaction or reminds of itself to get the adults' attention.

Initially, a baby perceives the world emotionally; therefore an adult's duty is to repeat many times the baby's primary sound pitch, thereby contributing to the stability of the first sounds of the baby's voice. On the $10^{\text {th }}$ to $12^{\text {th }}$ day of life a baby starts reacting to sounds, in the second month - freezes and listens to the sound of somebody's voice, violin playing, etc. According to G. Craig, in the very first weeks of their lives babies turn their heads towards a source of sound. Then at the age of two months their hearing ability decreases, but they regain the said ability at the age of three months since hearing perception reactivates in the end of the second month and in the beginning of the third month. At the age of three to four months a baby is able of discern sound direction and attempts to trace the sound source with his/her eyes. The development of the hearing analyzer in the brain continues up to the age of 2 years (Крайг, 2000, 238). The perceptive stage starts at the age of three to four months, when baby starts making his/her first voluntary sounds. Such sounds are regarded as the beginning of acquiring speech and singing skills. "Baby's voice sounds are sensory signals and orientating activities at the same time, which help form the first sound pitch notions in its mind," stresses B. Vikmane (Vikmane, 1995, 16). 
At the age of four to five months, an inclination to differentiate sounds of music can be observed: a baby reacts to the sound source, listens attentively to the intonation of a singing voice. During the first year of life, the baby joins in the adult's singing by humming or droning, later on it turns into murmuring, attempts making up first syllables. (See Table 4).

\section{Table 4 Sequence of formation of sound differentiation}

\begin{tabular}{|l|l|}
\hline $\mathbf{N}^{\mathbf{0}}$ & Stimulation of the child's sound differentiation during the 1st year of life \\
\hline 1. & The sound of mother's songs every day \\
2. & Singing, talking and playing promotes hearing, rhythm and memory \\
3. & $\begin{array}{l}\text { The abilities develop most intensively during the period when a baby has already } \\
\text { learned to crawl but does not speak yet }\end{array}$ \\
4. & $\begin{array}{l}\text { The baby feels the music nature and emotions; auditory perception is stimulated by } \\
\text { lullabies, dance songs }\end{array}$ \\
5. & $\begin{array}{l}\text { At the age of about } 6 \text { months the child is able to lull itself to sleep by making sounds } \\
\text { with its voice }\end{array}$ \\
6. & At the age of 10 months - smile and react with motions when hearing dance music \\
\hline
\end{tabular}

In response to the adult's sounds, the baby gradually becomes more and more animated. It manifests itself in the baby's smile, motor activity and vocalization. That is how the baby shows its readiness for communication. Communication with the adult, by which the child satisfies its communication needs with the adult, is realized by four stages of invariable sequence:

1. Child's attention and interest for the adult.

2. Child's emotional attitude to the adult.

3. Child's initiating activity.

4. Child's sensitivity to the adult's attitude (Лисина, 1997, 48).

It is very important, that in auditory perception and analysis, the vocalization apparatus plays the same role as eye movements in visual perception. The reproduction of a sound pitch may only be possible when the voice apparatus is engaged in the sound forming process. According to German educator P. Michel, the decisive preparatory stage for musical development involves the first 3 years of life. If the musical development is started in due time (during the first year of life), then till the preschool age $(3-7$ years) the child musical abilities - hearing, rhythm, memory - reach a definite level (Michel, 1973, 18). Thus, during the first year of life, the child's vocal experience has three levels, which promote both speech and musicality: the age of eight months is the early stage of melodic sounds, which is promoted by lullabies and child's own melodies; at the preverbal stage a child develops the ability of imitating consonants, syllables, which is stimulated by adults using rhythm elements; the stage of telling about vocal symbols and mastering of 
words, which is instigated by rational thinking (Papoušek, 1996, 44-45). (See Table 5).

Table 5 Child's (0-3) vocal experience

\begin{tabular}{|l|l|l|}
\hline \multicolumn{2}{|l|}{ Age } & Vocal experience \\
\hline & 1 & $\begin{array}{l}\text { 8 months is the early stage of melodic sounds, which is promoted by lullabies } \\
\text { and child's own melodies }\end{array}$ \\
\cline { 2 - 3 } 2 & 2 years & $\begin{array}{l}\text { At the preverbal stage a child develops the ability of imitating consonants, } \\
\text { syllables, which is stimulated by adults using rhythm elements }\end{array}$ \\
\cline { 2 - 3 } & $\begin{array}{l}\text { The stage of telling about vocal symbols and mastering of words, which is } \\
\text { instigated by rational thinking }\end{array}$ \\
\hline $\begin{array}{l}\text { A child can conscientiously reproduce intonations in music and responding to } \\
\text { 1) sings along with the adult finishes a sentence; } \\
\text { 2) joins in singing; } \\
\text { 3) joins with the movements: claps his hands, sits down, stamps his feet, spins } \\
\text { around, etc. }\end{array}$ \\
\hline 3 years & $\begin{array}{l}\text { The child may sing a short song, either individually or with a little support of } \\
\text { the adult, making various movements while he/she sings. }\end{array}$ \\
\hline
\end{tabular}

During the second year of life, child can conscientiously reproduce intonations in music. Responding to music, a child sings along with the adult, finishes a sentence, joins in singing, claps his hands, sits down, stamps his feet, spins around, etc. At the age of 3 to 4, individual variations in sound perception start appearing, so a child may sing a short song, either individually or with a little support of the adult, making various movements while he/she sings.

Musical activity inspires interaction between the development of thinking, emotions, creative imagination, voluntary attention, volition and musicality. The quality of development of child's musical abilities is promoted in view of the child's individual faculties, dispositions, needs and interests.

The research of the theoretical sources had revealed that the musical perception is not developed suddenly, just by itself. Careful educational work in this respect has to be done since the early years. The pedagogical observations during the preschool music teacher's work (1986-2015) confirm that the musicality in children differs. The opinion that in the majority of children the musical abilities get their demonstration at the age of 5-7 years is significant both for the educator's practice and this research. If the musical abilities get their development earlier, at the age of $3-5$ years, it acknowledges the child's musical talent. In practice the majority of the preschool children were with a low musical perception level and the singing skills - atypical for 5-7 years old children. Only 100 children out of 800 involved in the empirical research (2002- 
2012) possessed the musicality level adequate to the level described in the researched theoretical sources.

It stimulated finding out the children's musical environment conditions at home, subsequently in order to find individual approach and pedagogical means for fostering of musical perception of each child by music sessions, which had been organized for musicality development in group 2 times a week. By interviews with parents the musicality development opportunities from the birth till the age of 3 years at home it had been established that at home the parents seldom sing to the child or together with the child, seldom they use the opportunity to involve their children into groups of interests for children development. Together we organized the concerts for musicality development group, where were involved grandparents, parents, children and the music teacher in joint music making - sing-along.

By cooperation with the children's parents, the pedagogical means were found that and how should foster the musical perception development process since the child birth in practice. Namely, these are musical environment appropriate to the child age, the song content appropriate to the child age, positive attitude both at home and at group sessions, - purposeful joint musical activity by parents, the teacher and the children. The decisive factor is the teacher's tender attitude to the child's musical perception development succession, deep personal concern in the nurturing of the child's musicality development and responsibility for the result of the work - development of the child interested in musical activity.

\section{Conclusions}

The child's music perception development has been analysed from the prenatal period up to the age of three years through the research of the theoretical sources. The child music perception and hearing notions are being developed gradually simultaneously with the child's skill of singing and vocal development of the voice. During the early genesis stage the child's musical perception is being stimulated by the parents support while singing, speaking, playing. By the empirical research it was established that the child's musical hearing notions are developing at a differential tempo. It is important to initiate the child's musical activity in due time in appropriate environment by diverse music contents. 


\section{References}

Fassbender, C. (1996). Infant's auditory sensitivity towards acoustic parameters of speech and music. In: Deliege, I., Sloboda, J. (Eds.). Music Beginnings: origins and Development of Musical Competence. (pp. 56-87). New York: Oxford University Press.

Interval (music). (2015). Retrieved from https://en.wikipedia.org/wiki/Interval_(music)

Joffe, J. (1991). Muzikālās dzirdes attīstības ceļi. Rīga: Zvaigzne.

Krumhansl, C. L. (2000). Music Perception. In: Kazdin A. E. (Ed.), Encyclopedia of Psychology: (Vol. 5, pp. 363-368). Oxford: Oxford University Press.

Lecanuet, J. P. (1996). Prenatal auditory experience. In: Deliege, I., Sloboda, J. (Eds.). Music Beginnings: Origins and Development of Musical Competence. (pp. 3-34). Oxford, New York, Tokyo: Oxford University Press.

Līduma, A. (2015). Bērna muzikalitāte. Riga: Librum.

Līduma, A, (2004). Pirmsskolas vecuma bērnu muzikalitātes attīstības pedagogiskais aspekts Disertācija. Riga: LU PPI.

Michel, P. (1974). Music Education in GDR as a Means of an All-Round and Harmonious Development of Personality. In: Kabalevsky, D. (Eds.). Music Education in the Modern World: Materials of the $9^{\text {th }}$ Conference of the International Society for Music Education. (pp. 83-95). Moscow: Progress Publishers.

Papoušek, H. (1996). Musicality in infancy research: biological and cultural origins of early musicality. In: Deliege, I., Sloboda, J. (Eds.). Musical Beginnings: Origins and Development of Musical Competence. (pp. 37-55). Oxford, New York, Tokyo: Oxford University Press.

Vikmane, B. (1995). Latviešu tautasdziesma kā pirmsskolas vecuma bērnu muzikālās dzirdes un balss attīstīšanas līdzeklis. Mūzikas pedagoǵija. Rīga: LU.

Арисменди, А. Л. (1989). Дошкольное музыкальное воспитание. Пер. с испанского Ю. Ванникого. Москва: Прогресс.

Гальперин, С. И. (1965). Физиологические особенности детей. (с. 93-120). Москва: Просвещение.

Готсдинер, А. Л. (1974). О стадиях формирования музыкального всприятия. Сб. статей. Готсдинер, А. Л. (Сост.). (с. 230-251) Москва: Музыка

Крайг, Г. (2000). Психология развития. СанктПетербург: Питер.

Лисина, М. И. (1997). Общение, личность и психика ребенка. Рузская, А. Г. (Ред.). Москва: Ин-т практической психологии, Воронеж: НПО МОДЭК.

Мясищев, В., Готсдинер, А. (1992). Что есть музыкальность? (What is the musicality?). В: Музыкальная психология: (Раздел 4, с. 14-29). Москва: Моск. гос. консерватория им. П. И. Чайковского.

Никитин Б. П., Никитина Л. А. (1989). Mbl, наши дети и внуки. Москва: Молодая гвардия.

Радынова, О. П., Катинене, А. И., Палавандишвили, М. Л. (1994). Музыкальное воспитание дошкольников. Радынова, О. П. (Ред.) Москва: Просвещение: Владос. 